\title{
Cyclic AMP-Induced Slow Inward Current in Depolarized Neurons of Aplysia californica
}

\author{
JacSue Kehoe \\ Laboratoire de Neurobiologie, Ecole Normale Supérieure, 75005 Paris, France
}

Cyclic nucleotides have been implicated in many long-lasting transmitter-induced effects on membrane conductance. One previously observed effect of cAMP on molluscan neurons is to induce a slow inward current, which has been further evaluated here in depolarized anterior and medial cells of the pleural ganglion of Aplysia californica in order to understand better its underlying ionic mechanisms and its sensitivity to a variety of pharmacological agents. This current, which appears to be the only CAMP-induced current seen in the anterior cells, was shown to invert at about +25 $\mathrm{mV}$, that is, approximately $25-30 \mathrm{mV}$ inferior to $E_{\mathrm{Na}}$. This reversal potential was lowered by about 15-16 $\mathrm{mV}$ when half of the extracellular $\mathrm{Na}$ was replaced by either mannitol or $\mathbf{N}$-methyl-D-glucamine, whereas it was unaffected by changes in extracellular $\mathrm{Cl}, \mathrm{Ca}$, or $\mathrm{Mg}$. The response persisted in seawater in which the $\mathrm{Na}$ had been totally replaced by $K$, and its reversal potential shifted towards more negative values. These data are consistent with the hypothesis that both $\mathrm{Na}$ and $\mathrm{K}$ ions permeate the channel, with a $\mathrm{Na} / \mathrm{K}$ permeability ratio of approximately 2 . Ca ions do not appear to permeate the channel, but they do have a marked inhibitory effect on the response amplitude, as do $\mathrm{Mg}$ ions when $\mathrm{Ca}$ is not present. Caffeine, intracellular acidification, and phosphodiesterase inhibitors enhance and prolong the response without changing its reversal potential. Previous studies have shown that both caffeine and intracellular acidification inhibit phosphodiesterase, and it is assumed that the common effect of these manipulations on the CAMP-induced inward current is mediated, at least partially, by the inhibition of that enzyme. In the medial cells of the pleural ganglion, this slow inward current is present, but is dominated in the depolarized cell by a CAMP-induced diminution in a Ca-activated $K$ conductance (Kehoe, 1985b). This $K$ conductance and, consequently, the noninverting, cAMP-induced inward current that reflects its diminution, were shown to disappear in $\mathrm{Ca}$-free solutions, in the presence of isobutyl-1-methylxanthine (IBMX) or caffeine, and upon acidification of the cytoplasm. When this cAMP-sensitive $K$ conductance is blocked, the presence of the inverting cAMP-induced cationic current is unmasked. The CAMP-induced cationic current is shown to have many properties in common with cyclic nucleotideinduced currents described in photoreceptors, olfactory re-

\footnotetext{
Received Oct. 16, 1989; revised Mar. 15, 1990; accepted May 2, 1990.

This work was supported by the CNRS (URA 295), the INSERM (CRE 886005), and the Université Pierre et Marie Curie.

Correspondence should be addressed to JacSue Kehoe, Laboratoire de Neurobiologie, Ecole Normale Supérieure, 46 rue d'Ulm, 75005 Paris, France.

Copyright (c) 1990 Society for Neuroscience $0270-6474 / 90 / 103194-14 \$ 03.00 / 0$
}

ceptor cilia, and cardiac myocytes, all of which have been shown to be outwardly rectifying cationic currents that are inhibited by divalent cations and do not involve the activation of a cAMP-dependent kinase.

The recently discovered ability of neurotransmitters to initiate multistep intracellular processes that cause long-duration changes in membrane excitability has given us new insights into mechanisms causing long-term synaptic effects, as well as a new appreciation of the possible interactions between different synaptic inputs converging on a single postsynaptic cell. In molluscan neurons, many of these slow transmitter-induced changes in membrane conductance have been shown to be controlled by cyclic nucleotides (for reviews, see Connor and Hockberger, 1985; Levitan, 1985, 1988; Hockberger and Swandulla, 1987). One of these nucleotide-induced responses, seen as early as 1975 by Liberman et al., is a TTX-, ouabain-, and amiloride-insensitive slow inward current that is corrclated with an increase in intracellular $\mathrm{Na}$ (Aldenhoff et al., 1983; Connor and Hockberger, 1984a) and disappears when extracellular $\mathrm{Na}$ is replaced by Tris (Kononenko et al., 1983; Connor and Hockberger, 1984a; Swandulla and Lux, 1984), TMA (Aldenhoff et al., 1983; Connor and Hockberger, 1984a), saccharose (Aldenhoff et al., 1983), bis-tris propane (Connor and Hockberger, 1984a), mannitol (Kehoe, 1985a), or glucosamine (Hara et al., 1985), but persists when $\mathrm{Na}$ is replaced by lithium (Aldenhoff et al., 1983; Connor and Hockberger, 1984a; Hara et al., 1985). A similar nucleotideinduced current has recently been described in photoreceptors (Fesenko et al., 1985; Haynes et al., 1986; Matthews and Watanabe, 1987), olfactory receptor cilia (Nakamura and Gold, 1987), and myocytes (Egan et al., 1988).

In molluscan neurons, this Na-sensitive response is characterized by its selective activation by cAMP (see, however, Connor and Hockberger, 1984a), its sensitivity to extcrnal Ca (Aldenhoff et al., 1983; Hara et al., 1985; Kehoe, 1985a; but see also Kononenko et al., 1983), its atypical voltage dependence (Kononenko, 1981; Connor and Hockberger, 1984a; Hara et al., 1985; Kehoe, 1985a; Gillette and Green, 1987; but see also Kononenko et al., 1983), and its enhancement by intracellular acidification (Aldenhoff et al., 1983; Green and Gillette, 1988). However, findings concerning this cAMP-induced response have often been contradictory. First, it appears clear that in different molluscan preparations and in different cells in the same mollusc, the response can have slightly different characteristics (see, e.g., Limax vs. Aplysia neurons studied by Connor and Hockberger, 1985). Second, cAMP often elicits more than one type of conductance change in a given cell, and the multiple nature of the response can easily go undetected. Finally, studying the ionic mechanisms and pharmacological characteristics of a re- 
sponse for which the reversal potential is not measured provides a limited basis for conclusions.

In an attempt to better understand the mechanisms underlying the cAMP-induced slow inward current and to resolve certain contradictory findings present in the literature, experiments were designed to study the effects of ions and drugs on either side of the reversal potential of the cAMP-induced slow inward current. These studies were performed on two cell types: (1) anterior cells of the pleural ganglion of Aplysia californica, in which the slow inward current is the only cAMP-induced response yet observed; and (2) medial cells of the same ganglion, in which 2 other types of cAMP-induced conductance changes have already been described (Kehoe, 1985a, b). The analysis of the cAMP-induced response in this latter group of cells also provides the necessary background for understanding the cAMPmediated synaptic responses in the same cells (see Kehoe, 1985a, b, 1990).

Some of the data described in this paper were presented to the Society for Neuroscience (Kehoe, 1986).

\section{Materials and Methods}

The experimental preparation. The experiments described in this paper were performed on the anterior and medial cells of the pleural ganglia of Aplysia californica (see Kehoe, 1972b for cell nomenclature and Kehoe, 1985a for a description of the preparation). For each set of data described or illustrated, the cell type employed has been indicated.

Solutions. The normal seawater was composed of $480 \mathrm{~mm} \mathrm{NaCl}, 10$ $\mathrm{mM} \mathrm{KCl}, 10 \mathrm{mM} \mathrm{CaCl}_{2}$, and $50 \mathrm{mM} \mathrm{MgCl}_{2}$ and was buffered with $5 \mathrm{~mm}$ $\mathrm{NaOH}$ HEPES (pH, 7.8). The ganglion, fixed in a culture dish lined with Sylgard, was constantly perfused and maintained at room temperature.

When the concentration of either $\mathrm{CaCl}_{2}$ or $\mathrm{MgCl}_{2}$ was lowered, an equivalent concentration of the other divalent was usually used to replace it (see Figs. 2 and 9); however, when the total divalent concentration was reduced, an isosmotic concentration of $\mathrm{NaCl}$ was used for the relevant replacement (see Fig. 3).

In low-Na or $\mathrm{Na}$-free solutions, $\mathrm{NaCl}$ was replaced, as indicated, by mannitol (see Kehoe, 1985a), $N$-methyl-D-glucamine $(\mathrm{HCl}$ ), or $\mathrm{KCl}$ When $\mathrm{NH}_{4} \mathrm{Cl}$ was used to alter the intracellular $\mathrm{pH}$, its addition was compensated for by an equivalent reduction in the $\mathrm{NaCl}$ concentration. In half- $\mathrm{Cl}$ solutions, $\mathrm{Cl}$ was substituted by isethionate or sulphate (Kehoe, 1972a). The fact that these and/or other impermeant anions chelate $\mathrm{Ca}$ or acidify the cytoplasm is discussed where relevant.

Drugs. Isobutyl-1-methylxanthine (IBMX), aminophylline, cAMP, guanosine 3',5'-cyclic monophosphate (cGMP), caffeine, and an inhibitor of cAMP-dependent protein kinase extracted from the bovine heart were all Sigma products. Tetracthylammonium (TEA) chloride was obtained from ICN Pharmaceuticals; Ro 20-1724 was a gift from Hoffmann La Roche. Bath-applied drugs were all dissolved in seawater at the final desired concentration prior to being introduced into the perfusion system.

Intracellular injection of drugs. Double-barreled electrodes were used for intracellular ionophoresis of EGTA $(250 \mathrm{~mm}$ dissolved in $500 \mathrm{~mm}$ $\mathrm{KOH})$ or for the Na salt of cAMP or cGMP $(250 \mathrm{mM})$. The second barrel was always filled with $\mathrm{K}_{3} \mathrm{SO}_{4}$, and currents were generated by a WPI microionophoresis unit. Parameters of the specific injection currents are given in the figure legends. $\mathrm{CaCl}_{2}(250$ or $500 \mathrm{~mm})$ was injected by pressure from a single-barreled electrode, as was the inhibitor of cAMP-dependent protein kinase (Sigma, P-8140). The latter substance (at a concentration of $1 \mathrm{mg}$ protein $/ 200 \mu \mathrm{l}$ solution) was dissolved in $250 \mathrm{mM} \mathrm{K}_{2} \mathrm{SO}_{4}$ containing $2 \mathrm{mg} / \mathrm{ml}$ fast green in order to both minimize the perturbation of normal membrane currents and permit the monitoring of the diffusion of the injected substance into the cell.

Methodological considerations. Unless otherwise specified, each experimental conclusion reported in this and the following paper (Kehoe, 1990 ) has been based on at least 5 confirmatory experiments. All control records in the figures represent stable responses obtained by repeated injections given at a constant interinjection interval that was different for different preparations and different cell types. The interinjection interval was usually on the order of $2-3 \mathrm{~min}$ for experiments performed on the anterior cells and up to 3-10 min for those performed on the medial cells. The values were determined empirically for each cell in order to assure stable holding currents and repeatable cAMP-induced response amplitudes.

None of the experimental, pharmacological or ionic manipulations made here activated synaptic input to the medial cells. Consequently, there was no indication that these manipulations provoked an increase in baseline cAMP levels that could explain any of the results obtained here.

The rapid transients seen in some of the records taken from depolarized anterior cells reflect the electrotonic spread of axonic action potentials into the soma of the cell where the recording, clamping, and cAMP injections took place. Other occasional small rapid transients on some records reflect artifacts caused by the perfusion system.

Electrodes, voltage-clamp, and recording procedures. A description of the electrodes, voltage-clamp design, and recording procedures has been published previously (Kehoe, 1985a).

\section{Results}

Although the cAMP-induced slow inward current has been studied in many different molluscan preparations, the evaluation of this current had been made exclusively at hyperpolarized membrane potentials (see Connor and Hockberger, 1984a for the only exception). The first 7 figures presented below illustrate this current in anterior cells and describe its ionic and pharmacological sensitivities on either side of its reversal potential.

The cAMP-induced slow inward current in anterior cells

Voltage dependence. One of the characteristics of the cAMPinduced inward current is its failure to increase in amplitude with hyperpolarization of the cell membrane beyond the resting potential (see Aldenhoff et al., 1983; Connor and Hockberger, 1984a; Kehoe, 1985a; Matsumoto et al., 1988). Two experiments showing the voltage dependence of this response are illustrated in Figure 1, where the raw data are presented in $A$ and $B$ and the current amplitudes plotted against holding potential are shown in $C$. As can be seen in Figure $1 C$, there is even a decrease in the amplitude of the response to the nucleotide injection as the membrane is hyperpolarized from -40 towards $-100 \mathrm{mV}$. When the cell is depolarized, there is an eventual reversal $\left(E_{\text {rev }}\right.$ at +18 and $+25 \mathrm{mV}$ in $A$ and $B$, respectively) and the appearance of a marked outward rectification. Similar characteristics were found in all the anterior cells studied $(n>20)$. The minimum reversal potential observed was that of $+18 \mathrm{mV}$, as seen in Figure $1 A$; the maximum, $+30 \mathrm{mV}$. Values higher than $+25 \mathrm{mV}$ were rarely observed, and $E_{\text {rev }}$ was most frequently located at about $+25 \mathrm{mV}$

Effect of alterations in $(\mathrm{Ca})_{0}$. As can be seen in Figure 2, there was no change in reversal potential associated with the very marked enhancement of the response that occurred in low-Ca seawater. Measurements made in many experiments (not shown) have revealed that the reversal potential is likewise unaffected by increasing extracellular $\mathrm{Ca}$ (to $60 \mathrm{~mm}$ ). The reduction in the response in high-Ca seawater takes place progressively, but rapidly. However, a total elimination of the response in high-Ca seawater such as seen in Figure 2 is not inevitable.

Although the outward rectification of the current was sometimes slightly reduced after prolonged exposure to $\mathrm{Ca}$-free seawater (see Fig. 2), it was never eliminated. An effect on the response amplitude of lowering or raising external $\mathrm{Ca}$ becomes visible within less than a minute following exposure of the ganglion to the altered Ca concentration, and grows over time (up to about $30 \mathrm{~min}$ ).

Effect of alterations in $(M g)_{0}$. As shown in Figures 2 and 3, the removal of extracellular $\mathrm{Ca}$ causes a marked enhancement 


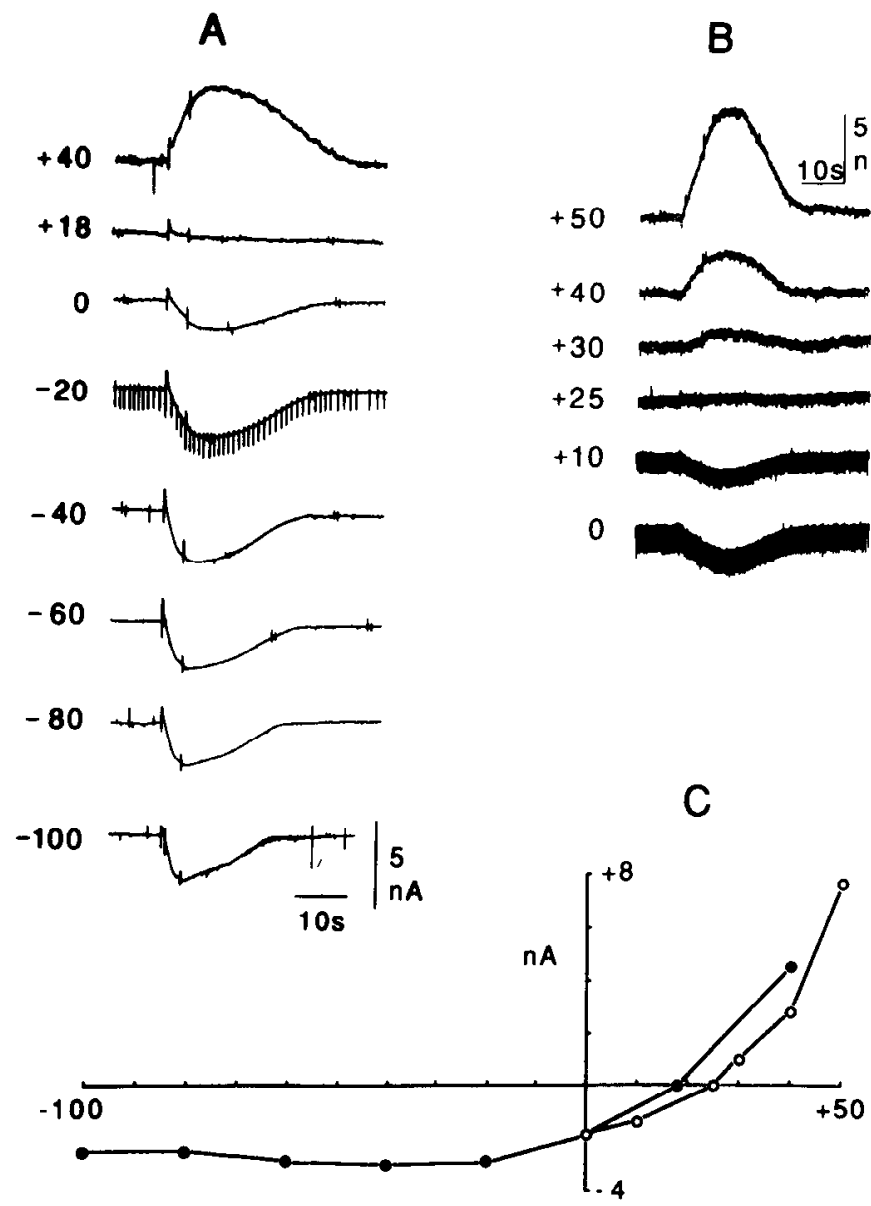

Holding potential ( $m V$ )

Figure 1. Responses of $2(A, B)$ different anterior cells (see Kehoe, $1972 a)$ to intracellular injection of cAMP. Note the reversal potential $(A,+18 \mathrm{mV} ; B,+25 \mathrm{mV})$. In $C$, the currents presented in $A$ and $B$ are plotted as a function of holding potential ( $A$ as solid circles, $B$ as open circles), revealing the outward rectification typical of this response. cAMP injection parameters: $A, 200 \mathrm{nA}, 4 \mathrm{sec} ; B, 100 \mathrm{nA}, 5 \mathrm{sec}$.

of the slow inward current, even with as much as $60 \mathrm{~mm}(\mathrm{Mg})_{0}$ present. In contrast, only a small increase in response amplitude was seen when the normal $50 \mathrm{mM}(\mathrm{Mg})_{0}$ was eliminated $\left(\mathrm{MgCl}_{2}\right.$ was replaced by an isosmotic concentration of $\mathrm{NaCl}$ ) if the normal $10 \mathrm{mM}(\mathrm{Ca})_{0}$ was maintained in the seawater (see Fig. $3 \mathrm{~A}$ ). An inhibitory effect of $\mathrm{Mg}$ can be revealed, however, if no Ca ions are present in the seawater. A comparison of the 2 sets of experiments in Figure $3, A$ and $B$, shows that, whereas the removal of $\mathrm{Mg}$ from the seawater (replaced by $\mathrm{NaCl}$ ) has little effect on the amplitude when $10 \mathrm{~mm} \mathrm{Ca}$ is present (Fig. $3 A$ ), a reduction of $\mathrm{MgCl}_{2}$ from 60 to $10 \mathrm{~mm}$ causes a marked enhancement of the response if $\mathrm{Ca}$ has been removed (Fig. $3 B$ ). The relative efficacy of the 2 divalent cations in inhibiting the cAMP-induced inward current can also be evaluated by observing the amplitude of the response in the 2 experimental conditions of Figure $3 A$, in which the total concentration of divalent cations in the seawater is the same, but the choice of divalent cations is different: in $10 \mathrm{~mm} \mathrm{Ca}, 0 \mathrm{mM} \mathrm{Mg}$, the response is very small, having shown practically no enhancement due to the removal of $\mathrm{Mg}$; in $0 \mathrm{~mm} \mathrm{Ca}, 10 \mathrm{~mm} \mathrm{Mg}$, it is markedly enhanced. Unfortunately, the cells do not resist divalent-free solutions, nor do they survive an evaluation over a wide voltage range in low-divalent ion concentrations (e.g., in $0 \mathrm{Ca}, 10 \mathrm{Mg}$; or $10 \mathrm{Ca}, 0 \mathrm{Mg}$ ). These limitations account for the failure to explore these parameters more completely.

Effects of alterations in $(\mathrm{Ca})_{i}$. Neither an intracellular injection of $\mathrm{Ca}$ (sufficient to elicit a large increase in $\mathrm{K}$ conductance) nor an influx of $\mathrm{Ca}$ caused by a brief depolarization altered the amplitude of the cAMP-induced slow inward current. Likewise, the cAMP-induced response and its enhancement by low $(\mathrm{Ca})_{0}$ were unaffected by an injection of EGTA that was shown to be sufficient for blocking depolarization-induced $\mathrm{K}_{\mathrm{Ca}}$ conductances.

Dependence on $(N A)_{0}$. The current-carrying role of $\mathrm{Na}$ was tested directly here by experiments in which either mannitol or $N$-methyl-D-glucamine was used to replace half of the normal $\mathrm{Na}$ in the seawater bathing the ganglion. As can be seen in Figure 4 , such a reduction in external $\mathrm{Na}$ caused a lowering of the reversal potential of the response by about $15-16 \mathrm{mV}$, that is, close to the $17 \mathrm{mV}$ predicted by the Nernst equation for a $\mathrm{Na}$ specific response. The concomitant change in $\mathrm{Cl}$ concentration occurring when half the $\mathrm{NaCl}$ is replaced by mannitol cannot explain the shift because, if a cAMP-induced diminution in $\mathrm{Cl}$ permeability contributed to the response, removing extracellular $\mathrm{Cl}$ would cause a movement of the reversal potential in the opposite direction of that observed. The lack of involvement of $\mathrm{Cl}$ permeability changes was confirmed by experiments in which half of the $\mathrm{Cl}$ was replaced with either isethionate or sulphate; in neither case was a change in the reversal potential observed (not shown). Note that the experiment illustrated in Figure $4 A$ was performed in low-Ca seawater $\left[1 \mathrm{~mm}(\mathrm{Ca})_{0}\right]$ in order to cnhance the responsc, bccausc lowering $(\mathrm{Na})_{0}$ always causes a marked reduction in the cAMP-induced response at all holding potentials (see Fig. 4A, second column). However, control experiments performed in normal $10 \mathrm{mM}(\mathrm{Ca})_{0}$ showed the same $\mathrm{Na}$ dependence of the reversal potential, though the responses were more difficult to measure and illustrate because of their reduced amplitude.

Although earlier experiments suggested, and the above findings illustrate directly, that $\mathrm{Na}$ ions are the main carrier of the inward current, the reversal potential of this current is clearly distinct from the $\mathrm{Na}$ equilibrium potential, $E_{\mathrm{Na}}$, which has been estimated to be about $+50 \mathrm{mV}$ in Aplysia neurons in normal seawater (see, e.g., Adams and Gage, 1979). One possible explanation for this difference is to assume that the cAMP-activated channels are also permeable to $\mathrm{K}$ ions.

Role of $K$ ions. When the external $\mathrm{K}$ concentration is halved, no change is observed in the reversal potential. However, the fact that $K$ ions do permeate the channel is revealed when the $\mathrm{NaCl}$ in the seawater is entirely replaced by $\mathrm{KCl}$. Under those conditions ( $490 \mathrm{M} \mathrm{KCl}$ ), as seen in Figure 5, the reversal potential shifts in a negative direction (by $\sim 15-16 \mathrm{mV}$ ), and, in this experiment, seemed to settle at around $+10-12 \mathrm{mV}$. In most such experiments, the reversal potential failed to stabilize at a fixed value in the high- $K$ seawater, undoubtedly as a result of the cell's high permeability to $\mathrm{K}$ ions.

Effect of phosphodiesterase inhibitors. The effects on the slow inward current of 3 different phosphodiesterase inhibitors (aminophylline, Ro 20-1724, and IBMX) were evaluated. Adding any 1 of the 3 to the bathing solution (at concentrations ranging from $100 \mu \mathrm{M}$ to $1 \mathrm{mM}$ ) causes a prolongation of the response that is sometimes associated with an enhanced amplitude. IBMX, which prolongs the response at concentrations lower than 50 


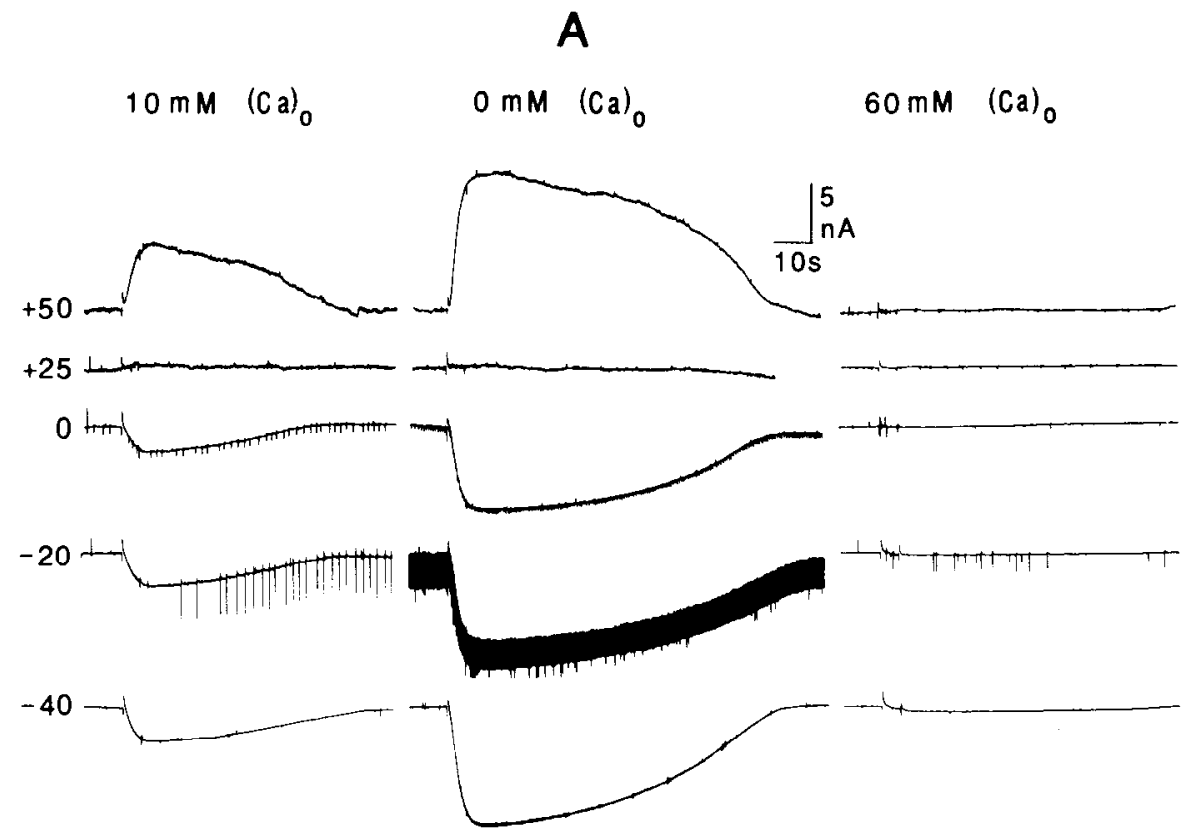



Holding potential $(\mathrm{mV})$
Figure 2. Effect of changes in external Ca concentration on cAMP-induced response in depolarized anterior cell. In spite of a marked change in the amplitude of the cAMP-induced current [enhanced by a $30-\mathrm{min}$ exposure to $\mathrm{Ca}$ free seawater, and almost completely eliminated in $60 \mathrm{~mm}(\mathrm{Ca})_{0}$ ], changes in $(\mathrm{Ca})_{0}$ fail to affect the reversal potential of the response. Likewise, the outward rectification typical of this response persists in Ca-free seawater, though it is slightly reduced. Alterations in $\mathrm{CaCl}_{2}$ were compensated for by opposite and equal alterations in $\mathrm{MgCl}_{2}$ concentrations. cAMP injection parameters: 110 $\mathrm{nA}, 5 \mathrm{sec}$. $\mu \mathrm{M}$, is considerably more effective than either of the other 2 compounds, for which effective concentrations are an order of magnitude higher.

As can be scen in Figurc 6, in spite of the marked transformation in the time course of the response in $200 \mu \mathrm{M}$ IBMX, there was no apparent change in either the reversal potential or in the voltage dependance of the slow inward current. Likewise no effect on the holding potential of the anterior cells was observed in the presence of IBMX (not shown).

Effect of intracellular acidification. Previous investigators have observed that intracellular acidification enhances the amplitude of the cAMP-induced inward current (Aldenhoff et al., 1983; Green and Gillette, 1988). As was shown in Figure 7, the enhancement resulting from intracellular acidification, like that induced by a reduction in extracellular $\mathrm{Ca}$ or by phosphodiesterase inhibitors, was found not to be associated with a change in the reversal potential of the response. In the experiment illustrated in Figure 7, the cytoplasm was acidified by means of an intracellular injection of $\mathrm{H}^{+}$ions. Similar findings were ob- tained when acidification of the cytoplasm was produced by a preexposure of the ganglion to 20 or $50 \mathrm{mM} \mathrm{NH}_{4} \mathrm{Cl}$ (see Green and Gillette, 1988; Kehoe, 1990). In neither type of experiment was the outward rectification significantly altered.

Effect of caffeine. Bathing the ganglion in $2 \mathrm{~mm}$ caffeine likewise causes a prolongation of the inward current seen in the anterior cells (not illustrated) without changing its reversal potential (see also Egan et al., 1988; Kehoe, 1990).

\section{The CAMP-induced response in medial cells}

The above experiments were performed in the anterior cells of the pleural ganglion. The following section reports similar studies performed on the medial cells of the same ganglion (see Kehoe, 1972b), in which it has been previously shown that cAMP, in addition to activating the above-described inward current, blocks 2 distinct $\mathrm{K}$ conductances (see Kehoe, 1985a, b). In the previous studies, the cAMP response was examined only at hyperpolarized membrane potentials, and very little evaluation was made of the slow inward current. The experi- 
A

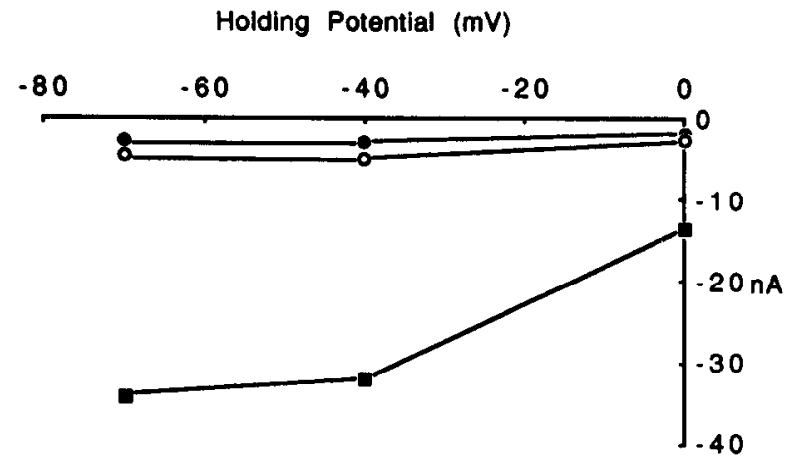

$-10 \mathrm{Ca} 50 \mathrm{Mg} \quad-10 \mathrm{CaOMg} \rightarrow-0 \mathrm{Ca} 10 \mathrm{Mg}$
B

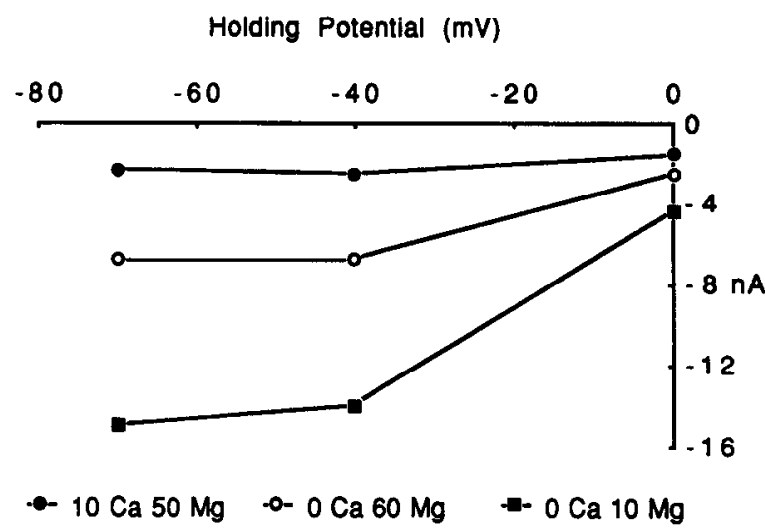

Figure 3. Comparison of inhibitory effects of $\mathrm{Ca}$ and $\mathrm{Mg}$ ions on cAMP-induced slow inward current. $A$, When the normal $10 \mathrm{mM} \mathrm{CaCl}$, is maintained in the seawater, complete replacement of the normal $50 \mathrm{mM} \mathrm{MgCl}_{2}$ with isosmotic $\mathrm{NaCl}$ has little effect on the cAMP-induced inward current (solid vs open circles, respectively). On the other hand, replacement of the $10 \mathrm{mM} \mathrm{CaCl}_{2}$ with an equivalent concentration of $\mathrm{MgCl}_{2}$, thereby maintaining both constant ionic strength and osmolarity, reveals the much greater blocking effect exerted by $\mathrm{Ca}$ ions than by $\mathrm{Mg}$ ions on the response. cAMP injection parameters: $100 \mathrm{nA}, 6 \mathrm{sec}$. $B$, A comparison of the solid-circle curve with the open-circle curve reveals that removal of $\mathrm{CaCl}_{2}$ from the seawater, even in the presence of $60 \mathrm{mM} \mathrm{MgCl}_{2}$, enhances the response. Further enhancement can be seen to occur, however, when the $\mathrm{MgCl}_{2}$ is also reduced. cAMP injection parameters: $60 \mathrm{nA}, 5 \mathrm{sec}$. The experiments illustrated in $A$ and $B$ were made on cells from different ganglionic preparations. In both cases, the ganglia were exposed to each solution for approximately 30 min, applied in the order presented above.

ments to be described below were performed on the medial cells and were designed for separating, by ionic and pharmacological means, the different components of the cAMP-induced conductance change in those cells.

Voltage dependence. The medial cell response to cAMP at depolarized potentials (see control records in Figs. 8, 9, 11, 12) differs from that seen in the anterior cells over a similar voltage range. The response is noninverting, lasts for tens of seconds, and is usually of maximum amplitude at around $+25 \mathrm{mV}$, that is, the reversal potential of the response seen in the anterior cells.

Effects of intracellularly injected cesium. When all $\mathrm{K}$ conductances in a medial cell are blocked, the cAMP response becomes monophasic and resembles the response seen in untreated an- terior cells. Such a transformation of the medial cell cAMP response can be seen by comparing the control records of Figure $8 A$ with those obtained after an intracellular injection of cesium. In Figure $8 B, \mathrm{I} / \mathrm{V}$ curves relating holding potential to the amplitude of the cAMP-induced currents measured in 2 other cesium-injected medial cells reveal that the voltage dependence of the response in the cesium-injected medial cells is the same as that seen in the noninjected anterior cells. The response inverts around $+25 \mathrm{mV}$ and shows marked outward rectification.

Effect of Ca-free solutions. It has previously been shown in the medial cells (Kehoe, 1985b) that a TEA-insensitive, Caactivated $\mathrm{K}$ current (triggered by a depolarizing pulse) is reduced by cAMP. Consequently, it was reasonable to suppose that the cesium-sensitive, noninverting element of the CAMP-induced
Figure 4. Effects of changing external $\mathrm{NaCl}$ concentration on reversal potential of cAMP-induced response in depolarized anterior cell. When half of the normal $(480 \mathrm{~mm}) \mathrm{NaCl}$ was replaced by mannitol (see Materials and Methods), there was a $16-\mathrm{mV}$ shift in the reversal potential of the CAMP-induced current $(A, B)$. Measurements were taken after a $20-\mathrm{min}$ exposure to the new solution. cAMP injection parameters: $100 \mathrm{nA}, 4 \mathrm{sec}$.






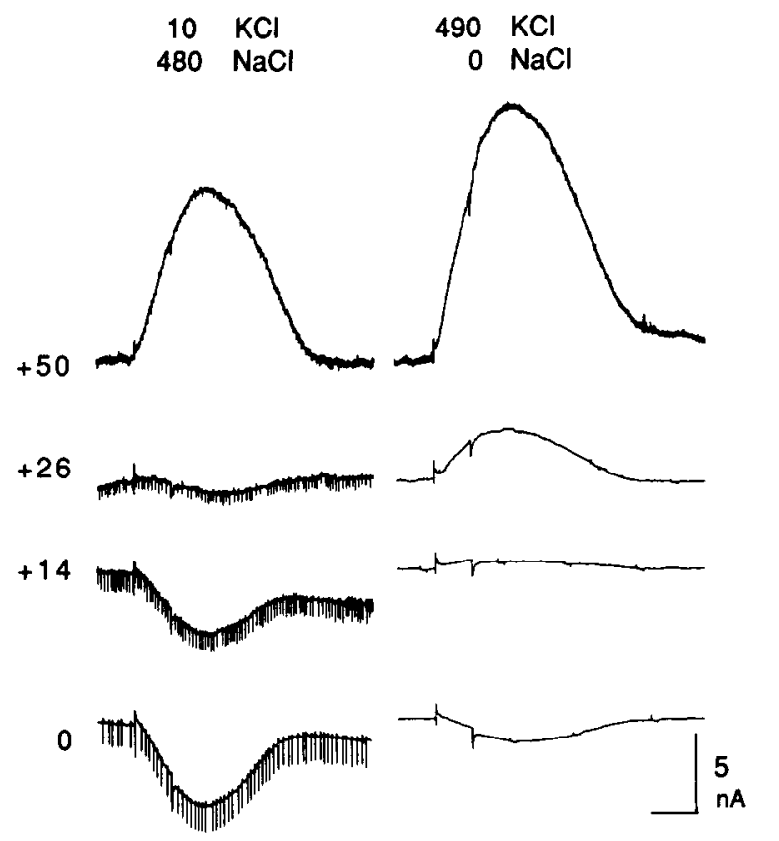

$10 \mathrm{~s}$

Figure 5. Effect on cAMP-induced inward current of total replacement of extracellular $\mathrm{Na}$ by $\mathrm{K}$. When $\mathrm{K}$ replaced $\mathrm{Na}$, the response to cAMP maintained its characteristic outward rectification. The reversal potential, on the other hand, shifted from about +28 to about $+12 \mathrm{mV}$, and the resting potential (not shown) moved from $-40 \mathrm{mV}$ to about +4 $\mathrm{mV}$. cAMP injection parameters: $100 \mathrm{nA}, 7 \mathrm{sec}$.

current in the depolarized medial cells reflected a diminution in such a Ca-activated $\mathrm{K}$ conductance. This hypothesis was confirmed by the finding that the noninverting element of the response disappears (Fig. 9A) or is markedly reduced (Fig. 9B) in Ca-free solutions.

The inverting element of the medial cell response appears to be enhanced in Ca-free seawater (see, e.g., Fig. $9 A,+5 \mathrm{mV}$ ). That this apparent enhancement is not simply due to the elimination of the cAMP-induced diminution in $\mathrm{K}$ conductance was confirmed by showing that, in cesium-injected medial cells in which all $\mathrm{K}$ conductances had been eliminated, the inverting element of the cAMP response that persists in those cells is, like the anterior cell response, enhanced by low $(\mathrm{Ca})_{0}$ and blocked by high $(\mathrm{Ca})_{0}$.

CAMP diminution of the TEA-insensitive $K$ conductance activated by an intracellular injection of $\mathrm{Ca}$. The effect of cAMP on the TEA-insensitive, Ca-activated $\mathrm{K}$ conductance in the medial cells can be demonstrated by another type of experiment



Figure 7. Effect of intracellular injection of $\mathrm{H}^{+}$ions on cAMP-induced current in depolarized anterior cell. An injection of $\mathrm{H}^{+}$ions (from a double-barrcled clectrode containing $250 \mathrm{~mm} \mathrm{HCl}$ in one barrel and $\mathrm{K}_{2} \mathrm{SO}_{4}$ in the other) causes an enhancement and prolongation of the cAMP-induced current (measured between 6-12 min after the acidifying injection) without altering the reversal potential of the response. The enhancement caused by the $\mathrm{H}^{+}$injection persisted well over $12 \mathrm{~min}$ after the termination of that injection. cAMP injection parameters: 100 $\mathrm{nA}, 5 \mathrm{sec} . \mathrm{H}^{+}$injection parameters: $20 \mathrm{nA}, 4 \mathrm{~min}$.

in which, rather than causing $\mathrm{Ca}$ to enter through voltage-activated channels, $\mathrm{Ca}$ is injected directly into a medial cell (held at $-40 \mathrm{mV}$, a potential at which little, if any, Ca-activated $\mathrm{K}$ conductance is spontaneously present). Such an experiment is illustrated in Figure 10, in which the most prominent $\mathrm{K}$ conductance thus activated is the slowly developing outward current that was previously shown (Kehoe, 1985b) to be unaffected by $10 \mathrm{mM}$ TEA. In contrast, the early, rapid K-dependent current (see Fig. 10, immediately following arrow), which was previously shown to be blocked by 2 mM TEA (see Kehoe, 1985b), is unaffected by cAMP (Kehoe, 1985b; see, however, results of Walsh and Byrne, 1989 on other Aplysia neurons).

It can be seen in Figure 10 that a brief injection of cAMP during the decay of the TEA-insensitive $\mathrm{K}$ current elicits a response that is clearly different from that seen prior to the $\mathrm{Ca}$ injection. In addition to the relatively rapid inward current seen in the control response (see Fig. 10, the cAMP response activated prior to the $\mathrm{Ca}$ injection), there is a more slowly developing, longer-lasting inward wave that reflects a diminution in the $\mathrm{Ca}$ activated $\mathrm{K}$ current, as can be deduced from the disappearance of the new element of the response when the cell is hyperpolarized to $E_{\mathrm{K}}$ (see Fig. $10 B$, which presents results from another, similar experiment).

The more slowly developing, Ca-activated $\mathrm{K}$ current could

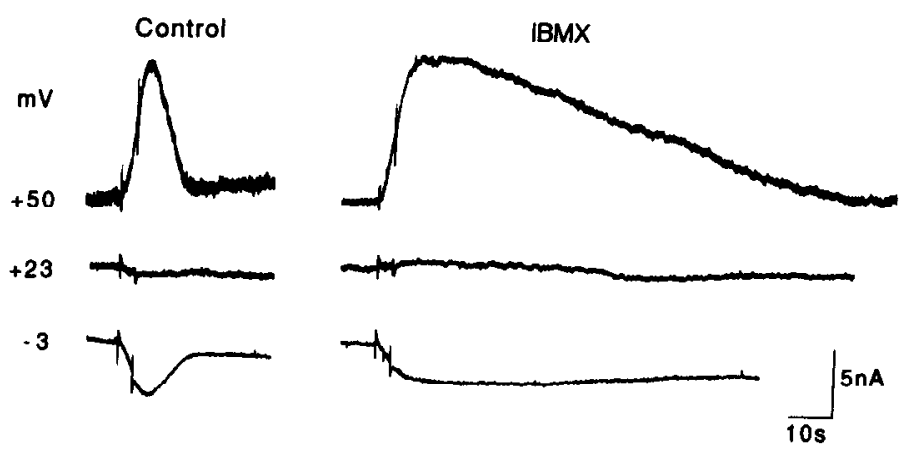

Figure 6. Effect of IBMX (15-min exposurc to $200 \mu \mathrm{M}$ ) on responsc of dcpolarized anterior cell to intracellular injection of cAMP. Note the marked increase in duration of the response in the presence of the phosphodiesterase inhibitor, as well as the failure of that inhibitor to alter the reversal potential or to cause an apparent change in the rectifying properties of the response. cAMP injection parameters: $50 \mathrm{nA}, 4$ sec. 
A

Control

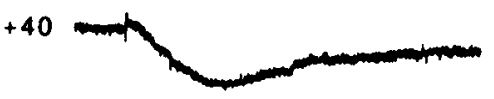

$+28$

$+10$

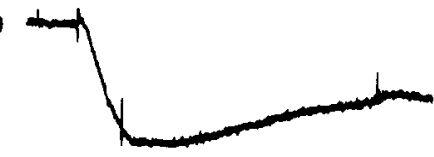

Cesium-injected
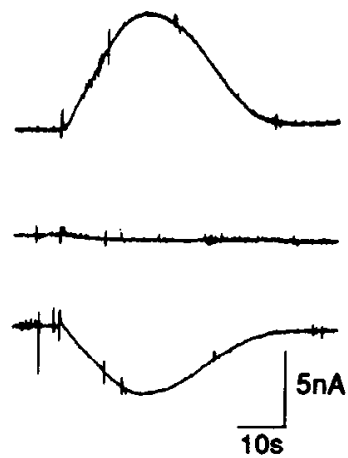

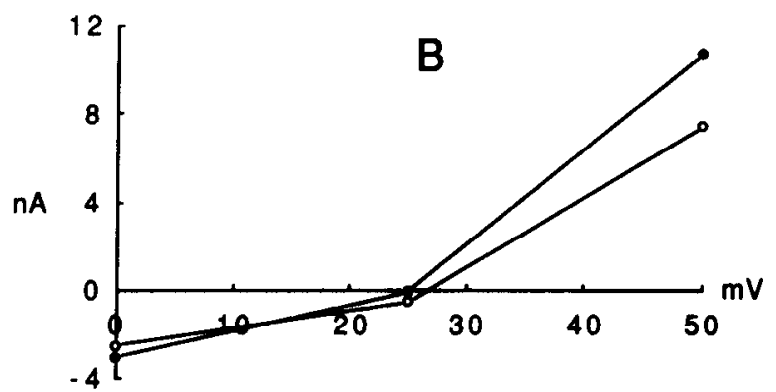

Figure 8. Response of depolarized medial cell to intracellular injection of cAMP before and after $\mathrm{K}$ conductance of cell is blocked by intracellularly injected Cs. $A$. The control records present a typical medialcell response to an intracellular injection of cAMP, characterized by the failure of the cAMP-induced current to invert. Following an intracellular injection of Cs (200 $\mathrm{nA}, 7 \mathrm{~min})$, the response to cAMP is transformed into one that is identical to that observed in the anterior cells (see Figs. 1-6). cAMP injection parameters: $200 \mathrm{nA}, 10 \mathrm{sec} . B$, The curves in the graphic presentation show the voltage dependence of the cAMP-induced response in 2 other cesium-injected medial cells. Note that, unlike the control response of the medial cells, as seen here or in the following figures, in the cesium-injected cell, the response inverts at about +25 $\mathrm{mV}$ and shows marked outward rectification like that of the response in the anterior cells. cAMP injection parameters: $200 \mathrm{nA}, 10 \mathrm{sec}$ (open circles); $100 \mathrm{nA}, 11 \mathrm{sec}$ (solid circles).

never be elicited in the anterior cells; in those cells, an injection of $\mathrm{Ca}$ ions activated only the rapid, early element of the composite response shown in Figure 10.

Effect of IBMX. As can be seen in Figure 11A, IBMX blocks the noninverting element of the cAMP-induced response elicited in a depolarized medial cell, leaving an inverting cationic response like that seen in the anterior cells. That the prolonged aspect of the residual current is indeed the result of the inhibition of phosphodiesterase by IBMX, rather than an indirect effect of the IBMX block of the noninverting element of the response, was confirmed in cells in which cesium had first been injected to block all $\mathrm{K}$ conductances.

The block of the TEA-insensitive, Ca-activated $\mathrm{K}$ conductance itself by bath-applied IBMX is revealed by the slow change in holding current that IBMX induces in the depolarized medial cell. The effect of IBMX on the current required to hold a medial cell at $+25 \mathrm{mV}$ can be seen in Figure $11 B$ (compare the inwardgoing movement in the holding current induced by IBMX with the dashed line indicating the steady-state holding current prior to application of IBMX). A similar experiment performed on anterior cells (not shown) reveals no change in holding current in response to an IBMX application; that is, the record from an anterior cell would be identical to that of the dashed line.

Effect of cytoplasmic acidification. As can be seen in Figure 12 , both elements of the cAMP response in depolarized medial cells are affected by intracellular acidification, whether the acidification is produced by an intracellular injection of $\mathrm{H}^{+}$ions or

A

Control Ca-free

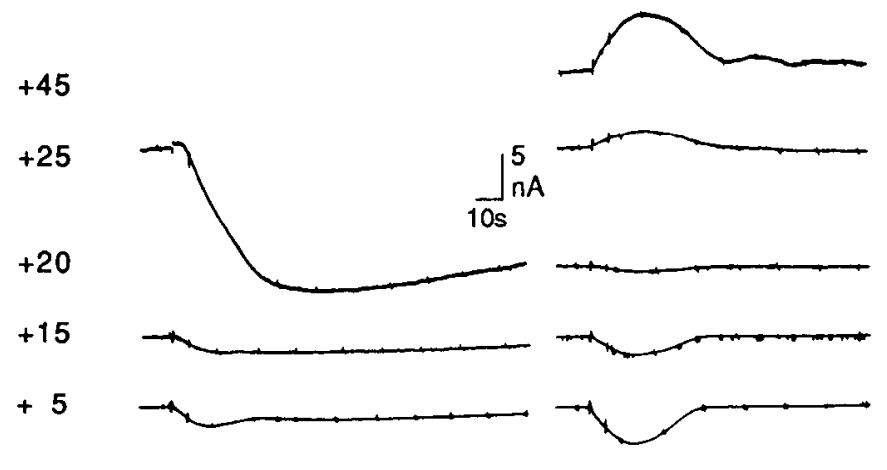

B

Control

Ca-free

$+40$
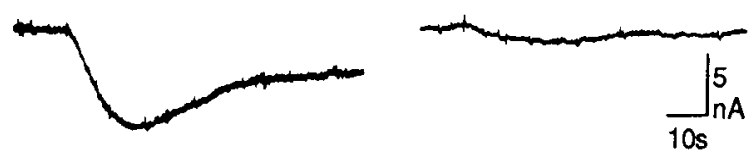

$+20$
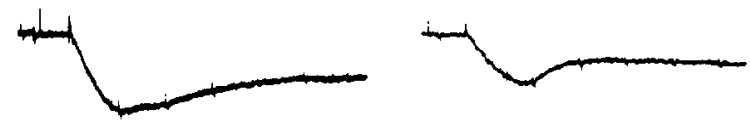

0
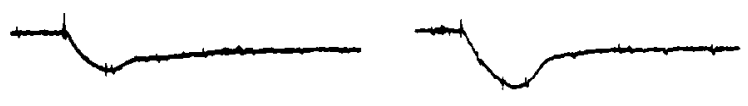

$-40$
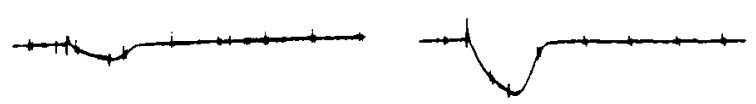

Figure 9. Effect of Ca-free seawater on response of depolarized medial cells to intracellular injection of cAMP. The control responses of the depolarized medial cells to an injection of cAMP are similar to those seen in Figure 8. When the ganglion is exposed to Ca-free seawater $(A$, 40 min exposure; $B, 33$ min exposure), there is an increase in membrane resistance (not shown), an elimination $(A)$ or marked diminution $(B)$ in the slow, consistently inward element of the response, and an enhancement of the remaining cationic component of the response. This transformation is the most striking in $A$, in which the slow inward current, dominant in the control condition, completely disappears in $0 \mathrm{Ca}$. cAMP injection parameters: $A, 150 \mathrm{nA}, 6 \mathrm{sec}, B, 100 \mathrm{nA}, 11 \mathrm{sec}$. 


\section{Diminution of Ca-activated $\mathrm{K}$ current by cAMP}
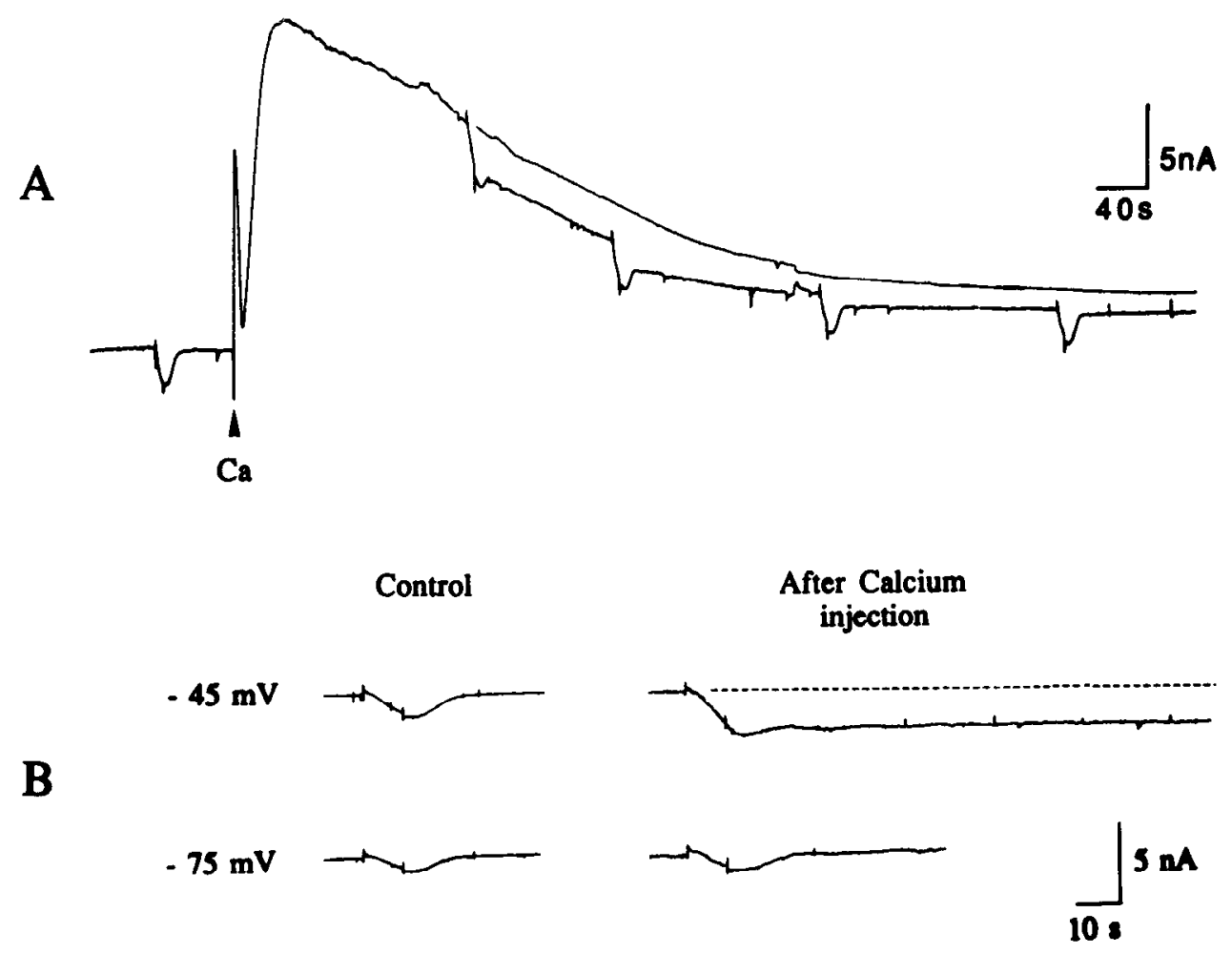

Figure 10. Effect of intracellular injection of cAMP on K conductance activated by intracellular pressure injection of $0.5 \mathrm{M} \mathrm{CaCl}$ in a medial cell held at $-40 \mathrm{mV}$. $A$, A $100-\mathrm{msec}$ injection of $\mathrm{CaCl}_{2}$ (see arrow) elicited a multicomponent change in membrane conductance in which the element most evident here is a long duration, TEA-insensitive increase in K conductance (Kehoe, 1985b). An intracellular injection of cAMP into the cell prior to the injection of Ca yields an inward current that returns rapidly to the baseline. In contrast, the responses to the 3 injections of cAMP made during the long-lasting increase in $\mathrm{K}$-conductance exhibit, in addition to the early inward current, a long-lasting inward tail that is not present in the response elicited prior to the intracellular injection of $\mathrm{Ca}$. The inward tail reflects a cAMP-induced diminution in the slow $\mathrm{K}$ conductance activated by Ca. cAMP injection parameters: $100 \mathrm{nA}, 10 \mathrm{sec} . B$. These records reveal, under another format, the response to cAMP (100 nA, 8 sec) before and after an intracellular pressure injection of $\mathrm{CaCl}_{2}(0.5 \mathrm{M}, 100 \mathrm{msec})$ measured at $-45 \mathrm{mV}$ and at $E_{\mathrm{K}}(-75 \mathrm{mV})$. The cAMP-induced response measured in control conditions is of a much shorter duration than that elicited during activation of the Ca-activated $\mathrm{K}$ conductance, as can be seen in the records made at $-45 \mathrm{mV}$. At $E_{\mathrm{K}}$, on the other hand, the responses elicited before and after the Ca injection are indistinguishable, showing that the long inward tail of the cAMP-induced response following $\mathrm{Ca}$ injection reflects a diminution in the Ca-activated $\mathrm{K}$ conductance. These records were made during a Ca-activated response that did not decay for a prolonged period, unlike that in $A$, where the $\mathrm{K}$ conductance decayed relatively rapidly. Note also the difference in time scales for $A$ and $B$. cAMP injection parameters: $100 \mathrm{nA}, 8 \mathrm{sec}$.

by preexposure to $\mathrm{NH}_{4} \mathrm{Cl}$. In both cases, the noninverting element disappears completely (as was the case in the presence of IBMX), due to an acidification-induced elimination of the Caactivated $\mathrm{K}$ conductance itself (see also Meech and Thomas, 1987). The remaining, cationic element is enhanced and prolonged, as it had been shown to be in acidified anterior cells (Fig. 7). The effects of $\mathrm{H}^{+}$injections such as those used in the experiment illustrated in Figure 12 persist for at least $20 \mathrm{~min}$, though they lessen with time. That the enhancing effect of acidification on the inverting element is indeed a direct one was confirmed, as in the experiments with Ca-free solutions or with IBMX, by evaluating its effects on medial cells in which the $\mathrm{K}$ conductances had first been eliminated by a cesium injection.

Effect of caffeine. $2 \mathrm{~mm}$ caffeine, like IBMX and intracellular acidification, affects both elements of the cAMP-induced response in the depolarized medial cells. In addition to enhancing (in normal as well as in cesium-injected cells) the cationic element that inverts at $+25 \mathrm{mV}$, it eliminates the noninverting element that has been shown to represent, under the conditions of these experiments, a diminution in the Ca-activated $\mathrm{K}$ conductance. As was shown to be the case for IBMX-treated or acidified cells, the disappearance of the slower element in caffeine-exposed cells is the result of the elimination of the $\mathrm{K}$ conductance being diminished by cAMP. That the Ca-activated $\mathrm{K}$ conductance was indeed blocked by caffeine was independently verified by observing the effect of that drug on the same conductance when activated by a brief depolarizing pulse. Using an experimental paradigm such as that used in previous studies of the TEA-insensitive, Ca-activated $\mathrm{K}$ conductance (Kehoe, $1985 \mathrm{~b}$ ), it was found that, in the presence of $2 \mathrm{~mm}$ caffeine, the long-lasting tail specific to the medial cells, and previously shown to be $\mathrm{Ca}$ activated (see Kehoe, 1985b), disappeared. Caffeine was, at $2 \mathrm{~mm}$, less effective in blocking the TEA-insensitive, $\mathrm{Ca}$ activated $\mathrm{K}$ conductance than was either IBMX or intracellular acidification, and at higher concentrations, this compound caused a marked degradation of the cell.

\section{Resistance of the CAMP-induced inward current to an intracellular injection of an inhibitor of cAMP-dependent protein kinases}

In order to determine whether or not the cAMP-induced inward current is dependent upon protein phosphorylation, an inhibitor 
$+50$

Figure 11. Effect of $200 \mu \mathrm{M}$ IBMX on cAMP-induced response in medial cells. $A$, The typical noninverting response of a medial cell to cAMP (Control) is transformed, by the addition of $200 \mu \mathrm{M}$ IBMX to the bath, into a response that, like that seen in the anterior cells, inverts at $+25 \mathrm{mV}(I B M X)$. The current remaining in IBMX is much more long lasting than the usual control cationic current (presumably due to the effect of IBMX on the phosphodiesterase), but it retains its characteristic outward rectifying properties. cAMP injection parameters: $100 \mathrm{nA}, 4 \mathrm{sec}$. $B$, The effect of IBMX on the current required to hold the cell at $+25 \mathrm{mV}$. The inward-going current triggered by application of IBMX to the bath reflects an IBMXinduced diminution in $\mathrm{K}$ conductance (compare holding current records following IBMX application with dashed line corresponding to the steady-state holding current value prior to drug application).

of cAMP-dependent protein kinase was injected into hyperpolarized anterior or medial cells. The slow inward cationic current was unaffected by a pressure injection of this inhibitor into the cell soma. Because the protein kinase inhibitor had been dissolved in a fast-green-containing solution, it was possible to verify that the inhibitor had penetrated the soma. Periodic tests of the cAMP-induced inward current revealed that, even $30 \mathrm{~min}$ after the entire soma had become a deep green, there was, at most, a slight slowing and small reduction in the response that also occurred with similar injections of the control solution.

In contrast, the same inhibitor, injected from the same electrode, was shown to completely block the 5-HT-induced diminution of the "S current" of the pleural sensory neurons. The 5-HT-induced diminution of that current was known by others (Shuster et al., 1985) to depend upon the activation of a cAMPdependent protein kinase. The block of the response of the sensory cells to ionophoretically-applied 5 -HT by the protein kinase inhibitor was obtained with significantly lower injected concentrations of the inhibitor than those used in the anterior or medial cell experiments, as measured by a visual inspection of the coloration of the respective cell bodies. Control injections, in which the solution containing $\mathrm{K}_{2} \mathrm{SO}_{4}$ and fast green was injected without the inhibitor, failed to block either the cAMPsensitive $\mathrm{K}$ conductance or its diminution by $5-\mathrm{HT}$.

\section{Discussion}

Further characterization of the cAMP-induced slow inward current

Ions carrying the slow inward current

The role of $\mathrm{Na}$ ions. The studies performed here on depolarized cells revealed a shift in reversal potential of about $15-16 \mathrm{mV}$

$\operatorname{IBMX}(+25 \mathrm{mV})$

\section{Control}
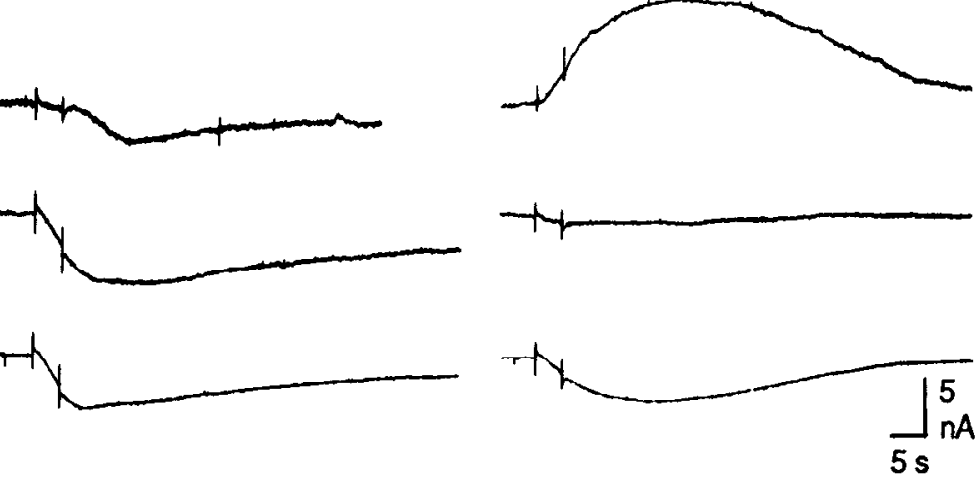

B

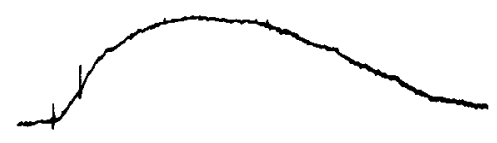

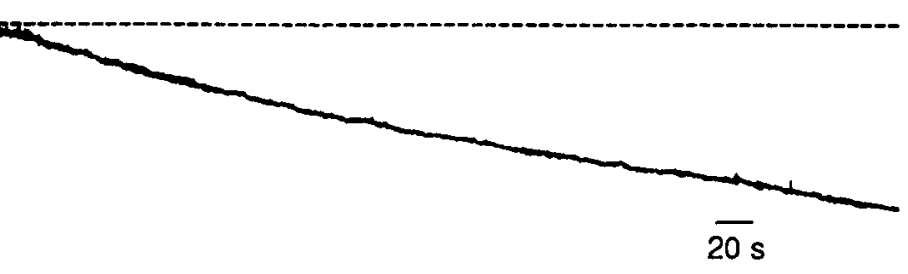

when half of the normal $\mathrm{NaCl}$ was replaced by either mannitol or $N$-methyl-D-glucamine, confirming the predominant role of $\mathrm{Na}$ ions in the generation of this response. However, the discrepancy between the $E_{\text {rev }}$ of the slow inward current $(\sim+25$ $\mathrm{mV})$ and the estimated $E_{\mathrm{Na}}(\sim+50 \mathrm{mV}$; see Adams and Gage, 1979) suggested that the channel opened by cAMP is not perfectly selective for $\mathrm{Na}$ ions.

The role of $K$ ions. Earlier investigations showed that changes in extracellular $\mathrm{K}$ concentration had no effect on the amplitude of the cAMP-induced response at resting potential (e.g., Connor and Hockberger, 1984a; Hara et al., 1985; Matsumoto et al., 1988; J. Kehoe, unpublished observations). However, as has been shown in Figure 5, when $\mathrm{Na}$ is completely replaced by $\mathrm{K}$, the inward current persists, confirming the hypothesis, suggested by the discrepancy between $E_{\mathrm{Na}}$ and the reversal potential of the slow inward current, that both $\mathrm{Na}$ and $\mathrm{K}$ ions cross the channel gated by cAMP (see also Swandulla and Lux, 1984).

$P_{N d} / P_{K}$. A quantitative expression of this hypothesis can be provided using a modified version of the Goldman-HodgkinKatz equation to express $P_{\mathrm{Na}} / P_{\mathrm{K}}$ as a function of $E_{\mathrm{Na}}, E_{\mathrm{K}}$, and the reversal potential $E_{\text {rev }}$ :

$$
\frac{P_{\mathrm{Na}}}{P_{\mathrm{K}}}=\frac{\left\{\exp \left[\left(E_{\mathrm{rev}}-E_{\mathrm{K}}\right) / 25\right]-1\right\} \cdot \mathrm{K}_{0}}{\left\{1-\exp \left[\left(E_{\mathrm{rev}}-E_{\mathrm{Na}}\right) / 25\right]\right\} \cdot \mathrm{Na}_{0}} .
$$

Using $E_{\mathrm{K}}=-80 \mathrm{mV}$ (Kehoe, 1972a), $E_{\mathrm{Na}}=+50 \mathrm{mV}$ (Adams and Gage, 1979), and $E_{\mathrm{rev}}=+25 \mathrm{mV}$ (this paper), Equation (1) yields a value of 2.16 for $P_{\mathrm{Na}} / P_{\mathrm{K}}$. Using this estimate for $P_{\mathrm{Na}} /$ $P_{\mathrm{K}}$, no detectable change in reversal potential would be expected when $\mathrm{K}_{0}$ is halved, confirming the findings reported here, and a shift of $17.2 \mathrm{mV}$ would be expected when all external $\mathrm{Na}$ is replaced by $\mathrm{K}$. This prediction is, again, very close to the ex- 


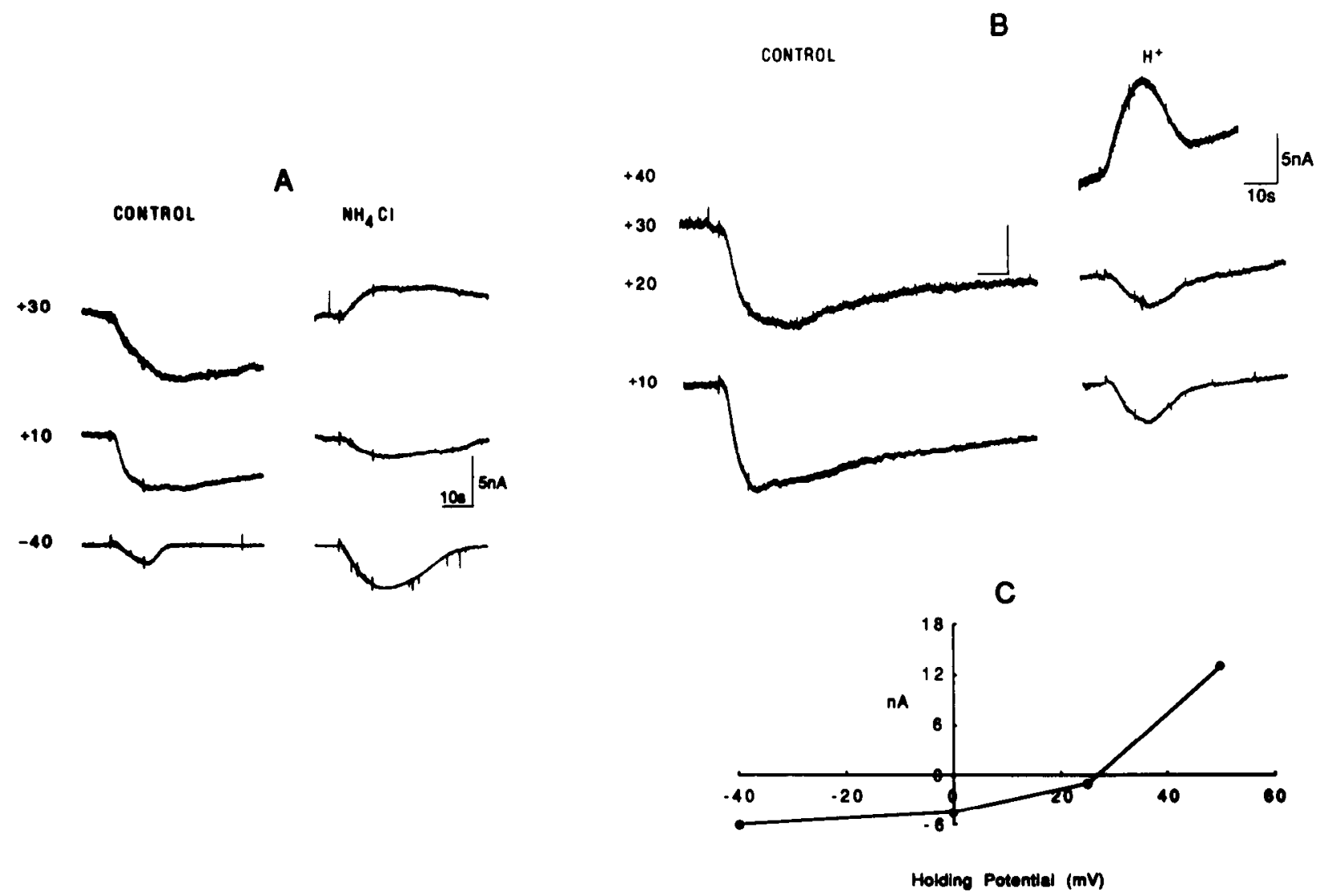

Figure 12. Effect of intracellular acidification on the cAMP-induced response in medial cells. $A$, The cytoplasm was acidified by first adding (for $25 \mathrm{~min}$ ), then removing (12-min wash), $50 \mathrm{mM} \mathrm{NH}_{4} \mathrm{Cl}$ to the seawater bathing the ganglion. During the period in which the cytoplasm can, from previous reports (Green and Gillette, 1988), be expected to be acidified (after return to normal seawater), there was an elimination of the noninverting cAMP response that is presumably due to an elimination of the CAMP-sensitive K current, as well as the revelation of the cAMP cationic current that inverts near $+25 \mathrm{mV}$. cAMP injection parameters: $150 \mathrm{nA}, 11 \mathrm{sec} . B$, In this experiment, the cytoplasm was acidified by injection of $\mathrm{H}^{+}$ions into the medial cell $(30 \mathrm{nA}, 300 \mathrm{sec})$. This acidification produced the same type of transformation in the cAMP-induced response as did exposure to $\mathrm{NH}_{4} \mathrm{Cl}$. The noninverting element of the cAMP-induced inward current is eliminated (by suppression of $\mathrm{K}$ conductance), exposing the presence of the cationic, inverting response to cAMP that was measured between 4 and $12 \mathrm{~min}$ after the end of the $\mathrm{H}^{+}$injection. The reversal potential and rectifying properties of the remaining response resemble those seen in the anterior cells. cAMP injection parameters: $100 \mathrm{nA}, 10 \mathrm{sec}$. $C$, The $\mathrm{I} / \mathrm{V}$ plot shows cAMP-induced responses measured in a third medial cell following injection of $\mathrm{H}^{+}$ions. Note the similitude between this curve and those shown in Figure 1.

perimentally obtained shift of $15-16 \mathrm{mV}$ seen in Figure 5. In spite of the high permeability to $\mathrm{K}$ ions when $\mathrm{Na}$ ions are replaced by impermeant ions, the amplitude of the slow inward current reduces progressively (see above). A similar diminution of "classical" transmitter-induced cationic currents in low-Na solutions was found by Ascher et al. (1978) to be due to a block of the channel by the impermeant cation Tris. No experimental analysis was made to try to determine the origin of the low-Na induced diminution of the current studied here, which occurred whether mannitol or $N$-methyl-D-glutamine was used for substituting $\mathrm{Na}$ ions.

Elimination of a possible contamination of the slow inward current by cAMP-induced diminutions in $\mathrm{K}$ or $\mathrm{Cl}$ conductances. In the anterior cells, it is clear that the cAMP-induced cationic current is not contaminated by a concomitant diminution in $\mathrm{K}$ conductance because blocking all $\mathrm{K}$ conductances with an intracellular injection of cesium had no effect on the amplitude, reversal potential, or voltage dependence of the response (J. Kehoe, unpublished data). Likewise, a contribution from a cAMP-induced diminution in $\mathrm{Cl}$ conductance could be excluded (see also Swandulla, 1987). Some investigators, however, re- ported an enhancement of the slow inward current (measured at resting potential) in low-Cl solutions and suggested that part of the net current might be due to a cAMP-induced diminution in $\mathrm{Cl}$ conductance. However, the substituting anions used in those experiments either chelate $\mathrm{Ca}$ and thereby lower the extracellular Ca concentration (sulphate, aspartate for Kononenko et al., 1983; gluconate for Aldenhoff et al., 1983) or acidify the cytoplasm (acetate for Kononenko et al., 1983; see Sharp and Thomas, 1981). Either one of these secondary effects of the anions used to replace $\mathrm{Cl}$ could well account for the marked increase that previous investigators have observed in the slow inward current (see effects of low-Ca seawater and intracellular acidification in Figs. 2 and 7, respectively).

Failure of changes in divalent concentration to affect the reversal potential. Neither $\mathrm{Mg}$ nor $\mathrm{Ca}$ ions appear to contribute to the current, at least in physiological solutions, because the reversal potential is unaffected by the complete removal of these divalents from the bathing medium. This finding is consistent with the data of Connor and Hockberger (1984a), who found, in Archidoris neurons, that the response that was eliminated in Nafree solutions was not associated with an increase in intracellular 
Ca as measured with arsenazo signals (see also the cAMP-induced current in Matsumoto et al., 1988). Slightly different conclusions, however, were drawn from certain previous studies on other neurons (e.g., in Helix by Kononenko et al., 1983; Swandulla and Lux, 1984; in Limax by Connor and Hockberger, 1985; in Aplysia by Hara et al., 1985). These authors arrived at the conclusion that $\mathrm{Ca}$ as well as $\mathrm{Na}$ ions can contribute to the cAMP-induced inward current, either because they observed an increase in intracellular $\mathrm{Ca}$ associated with the cAMP-induced current (Connor and Hockberger, 1985) or because they found that $\mathrm{Na}$-free solutions did not completely eliminate the response they studied (in hyperpolarized cells) when the normal Ca concentration was maintained [Kononenko et al., 1983; Connor and Hockberger, 1985 (certain cells only); Swandulla, 1987]. It remains to be seen whether $\mathrm{Ca}$ and $\mathrm{Na}$ are in fact both involved in the development of the current observed in some or all of those neurons, with both ions permeating the same channels, or whether the net inward current being observed in those studies is rather a composite current reflecting the activation of 2 independent, but coincident, events.

\section{Effects of divalent cations on the cAMP-induced response}

Effect of $(\mathrm{Ca})_{0}$ and $(\mathrm{Mg})_{0}$ on response amplitude. In all previously published studies but 1 (Kononenko et al., 1983; see below), a dramatic enhancement of the response was seen when $(\mathrm{Ca})_{0}$ was lowered (Aldenhoff et al., 1983; Hara et al., 1985; Kehoe, 1985a; Gillette and Green, 1987; Matsumoto et al., 1988). This finding is, of course, contrary to that which would be expected if $\mathrm{Ca}$ contributed directly to the current and suggests that this divalent cation, rather than carrying the current, exerts an inhibitory effect upon it. Evaluations of the effects of $\mathrm{Mg}$, the other divalent cation present in seawater, have led to less consistent conclusions. Some investigators working on Helix or Pleurobranchaea neurons found that $\mathrm{Mg}$ ions, like $\mathrm{Ca}$ ions, exert a blocking effect, though the inhibition by $\mathrm{Mg}$ ions was never found to be as strong as that exerted by $\mathrm{Ca}$ ions (Gillette and Green, 1987; Swandulla, 1987). When both $\mathrm{Ca}$ and $\mathrm{Mg}$ were replaced by $\mathrm{Na}$, Aldenhoff et al. (1983) observed, in Helix neurons, a marked increase in the amplitude of the response (measured at resting potential) over and above that seen when only $\mathrm{Ca}$ ions were deleted, but no evaluation was made of eliminating only $\mathrm{Mg}$ ions. In the experiments reported here (see Fig. 3), $\mathrm{Mg}$ ions appear to have little or no blocking effect under normal conditions but do reveal their inhibitory role when no other divalents are present.

Effects of $(\mathrm{Ca})_{i}$ on response amplitude. Experiments reported here have shown that the amplitude of the cAMP-induced slow inward current does not appear to be affected by changes in intracellular $\mathrm{Ca}$. This appears to be true whether free intracellular $\mathrm{Ca}$ is diminished by an injection of EGTA (see similar results of Hara et al., 1985 and studies in myocytes by Egan et al., 1987, 1988; but see also the contradictory findings of Gillette and Green, 1987) or is increased by intracellular injections of $\mathrm{Ca}$ (see also Gillette and Green, 1987; Green and Gillette, 1988). However, some previously reported studies (Kononenko et al., 1986) reported an increased response amplitude following an intracellular injection of $\mathrm{Ca}$. Increasing intracellular $\mathrm{Ca}$ could be expected, of course, to cause a net increase in the response to cAMP if, in the cell being injected, cAMP not only activated the slow inward current but also diminished a Ca-activated $\mathrm{K}$ current (see Fig. 10); it is not unlikely that such a mixed cAMPinduced response in the cells studied by Kononenko et al. (1986) explains their impression that increased $(\mathrm{Ca})_{i}$ caused an enhancement of the slow inward current.

Effects of $(\mathrm{Ca})_{0}$ and $(\mathrm{Mg})_{0}$ on voltage dependence. The atypical voltage dependence of the cAMP-induced slow inward current (see, e.g., Fig. 1; records in Connor and Hockberger, 1984a; Hara et al., 1985; Kehoe, 1985a, 1990) is not well understood. The marked outward rectification seen at depolarized potentials and the failure of the response to increase with hyperpolarization from resting to $-100 \mathrm{mV}$ yields an $\mathrm{I} / \mathrm{V}$ relationship that differs dramatically from that characterizing more typical transmitterinduced cationic conductances (e.g., Ascher et al., 1978).

In the cells studied by Gillette and Green (1987), in which there was a clear diminution in response amplitude with hyperpolarization, bathing the ganglion in $\mathrm{Ca}$-free solutions caused a clear flattening of the $\mathrm{I} / \mathrm{V}$ curve between -30 and $-70 \mathrm{mV}$. The authors attributed this transformation to an effect of extracellular $\mathrm{Ca}$ on the voltage dependence of the slow inward current itself. In this respect, the role of divalents on this response appears to be reminiscent of the effect of $(\mathrm{Mg})_{0}$ on the response to NMDA of central neurons (see Ascher and Nowak, $1988)$ and of both $(\mathrm{Ca})_{0}$ and $(\mathrm{Mg})_{0}$ on the nucleotide-induced responses seen in photoreceptors (Fesenko et al., 1985; Haynes et al., 1986) and olfactory receptor cilia (Nakamura and Gold, 1987; see below).

In contrast, removing $(\mathrm{Ca})_{0}$ did not seem to provoke such a marked transformation in the I/V curve of the cAMP-induced cationic current observed in either of the cell types studied here (see Figs. 2, 3; Kehoe, 1985a, 1990; Hara et al., 1985). A flattening and eventual inversion of the slope in that voltage range could sometimes be observed after a very long exposure to $\mathrm{Ca}$ free solutions, but during the early period of exposure over which marked enhancement occurred, little or no transformation of the $\mathrm{I} / \mathrm{V}$ curve could be seen.

I/V curves similar to the one seen by Gillette and Green (1987) in Ca-free seawater or to those observed here after long exposures to Ca-free or low-divalent solutions are still not the ohmic relationships that would be predicted for an increase in a cationic conductance. It is very possible, however, that under truly divalent-free conditions (a condition not practicable with the experimental procedures used here), the cAMP-induced slow inward current would completely lose its atypical voltage dependence, as do the nucleotide-induced currents in photoreceptors and olfactory receptor cilia.

\section{Effects of phosphodiesterase inhibitors, intracellular acidification, and caffeine}

Phosphodiesterase inhibitors prolong, and often enhance, the cAMP-induced inward current without altering its reversal potential. Similar effects were observed when the cytoplasm was acidified (either by an injection of $\mathrm{H}^{+}$ions or by preexposure to $\mathrm{NH}_{4} \mathrm{Cl}$-containing seawater) or when the ganglion was exposed to $2 \mathrm{~mm}$ caffeine. Because intracellular acidification (Calhoon and Gillette, 1983) and extracellular caffeine (Butcher and Sutherland, 1962) are both known to diminish phosphodiesterase activity, it is possible that the transformation in the response seen under these different experimental conditions reflects an increase in the lifetime of the injected cAMP. However, the first effect of intracellular acidification, when produced by an intracellular injection of $\mathrm{H}^{+}$ions, is to enhance rather than prolong the response. This suggests the possibility that acidification acts not only on the phosphodiesterase, but also on the channel properties itself, without, however, permeating the 
channel (Fig. 7; Swandulla and I ux, 1984). [It has been shown that depolarizing molluscan neurons causes changes in $\mathrm{pH}$ for which the acidification is maximum at around $+10 \mathrm{mV}$, with further depolarization shifting the intracellular $\mathrm{pH}$ in an alkaline direction (see Meech and Thomas, 1987). It cannot be excluded, consequently, that the voltage-gated $\mathrm{H}^{+}$conductance (Thomas and Meech, 1982) and consequent voltage-dependent changes in intracellular $\mathrm{pH}$ could contribute, in part, to the voltage dependence of the cAMP-induced response. However, the fact that the voltage-current relationship of the cAMP response is monotonic, whereas the curve relating voltage and intracellular $\mathrm{pH}$ is not, suggests that voltage-induced changes in $\mathrm{pH}$ did not have a dominant effect on the $\mathrm{I} / \mathrm{V}$ curve of the response as measured here.]

$\mathrm{II}^{+}$injections in the anterior cells elicit changes in membrane conductance that have not been analyzed or described here. However, the $\mathrm{H}^{+}$-induced conductance changes are limited to the duration of the injection itself and, consequently, cannot be directly responsible for the enhancing effect of the $\mathrm{H}^{+}$injection on the cAMP-induced response, because the enhancement persists for at least $10 \mathrm{~min}$ after even a very brief (tens of seconds) $\mathrm{H}^{+}$injection. There was no indication in the depolarized anterior cells that the $\mathrm{H}^{+}$injection caused any diminution in $\mathrm{K}$ conductances under the prevailing experimental conditions (see contrasting findings below for medial cells, in which a Ca-activated $\mathrm{K}$ conductance was shown to persist and to be blocked by $\mathrm{H}^{+}$ injections; see also Meech and Thomas, 1987).

Caffeine, in addition to interfering with phosphodiesterase, is known to produce an increase in intracellular free $\mathrm{Ca}$ in many cells. However, there is no indication that the increase and/or prolongation of the cAMP-induced inward current results from such a caffeine-induced effect. First, increasing intracellular $\mathrm{Ca}$ (whether by depolarizing pulses or by intracellular injection of that ion) did not cause such a transformation in the response, and second, adding $2 \mathrm{~mm}$ caffeine to the bathing medium did not cause an increase in $\mathrm{K}$ conductance, as would be expected if intracellular $\mathrm{Ca}$ had been significantly increased by that drug.

Comparison of the cAMP-induced response in the medial and anterior cells

cAMP-sensitive, $C a$-activated $K$ conductance

Confirmation of the presence of a cAMP-blocked, TEA-insensitive, Ca-activated $K$ conductance in the depolarized medial cells. In earlier experiments (Kehoe, 1985b), a TEA-insensitive, Ca-activated $\mathrm{K}$ conductance was shown to exist in the medial cells, revealed as a tail current recorded at resting potential following a 2-sec jump to $+20 \mathrm{mV}$. The tail current was shown to be diminished by permeant cAMP analogs, by synaptically activated increases in intracellular cAMP, and by phosphodiesterase inhibitors. The experiments described here, which were done on the depolarized medial cells, have confirmed and extended those results by showing that part of the holding current in those cells corresponds to a TEA-insensitive, Ca-activated $\mathrm{K}$ conductance and that both intracellular cAMP injections and IBMX block that element of the holding current.

Blockade of the TEA-insensitive, Ca-activated $K$ conductance. The experiments reported here have also revealed that intracellular acidification and caffeine share the blocking action of cAMP and IBMX on the Ca-activated $\mathrm{K}$ conductance. The common capacity of IBMX, intracellular acidification, and caffeine to inhibit phosphodiesterase again provides a tempting explanation for the blocking effect of these manipulations on this $\mathrm{K}$ conductance. However, Meech and Thomas (1987) also noted that $\mathrm{K}$ conductances in general in Helix neurons were inhibited by intracellular acidification, and it cannot be excluded that acidification might inhibit the Ca-activated conductance directly. On the other hand, it is clear that, though cAMP is known to induce acidification, none of the effects of cAMP observed here are mediated via a cAMP-induced change in $\mathrm{pH}$ (Connor and Hockberger, 1984b; see discussion of this hypothesis in Kehoe, 1985a), because the cAMP-induced conductance changes studied here occur much more rapidly than does the cAMP-induced pH change (Connor and Hockberger, 1984b).

Other cAMP-sensitive, Ca-activated $K$ conductances. It should be noted that other investigators working on other Aplysia neurons have described cAMP effects on the rapid, TEA-sensitive, Ca-activated $\mathrm{K}$ conductance (see Fig. 10A, which shows a rapid, early response to an injection of $\mathrm{Ca}$ into the medial cell; see also Kehoe, 1985b). Whereas some investigations have suggested that cAMP increases the activity of the underlying channel (DePeyer et al., 1982; Ewald and Eckert, 1983; Ewald et al., 1985), others have found more recently that cAMP diminishes that conductance (Walsh and Byrne, 1989). It was shown previously (Kehoe, 1985b) that, in the medial cells, the TEA-sensitive, Ca-activated $\mathrm{K}$ conductance was unaffected by cAMP. These various findings, all describing the effects of cAMP in different Aplysia neurons on 2 different $\mathrm{Ca}$-activated $\mathrm{K}$ conductances, reveal the cell specificity, as well as channel specificity, of cAMP actions.

Absence of the TEA-insensitive, Ca-activated $K$ conductance in the anterior cells

The data described above have clcarly shown that the differential response of the anterior and medial cells to cAMP injection (single component vs multicomponent) reflects the absence, in the anterior cells, of the TEA-insensitive, Ca-activated $\mathrm{K}$ conductance. This was shown by the failure of a depolarizing jump to induce a long-lasting, TEA-insensitive, K-dependent tail current in those cells, as well as by the failure of an intracellular injection of $\mathrm{Ca}$ to elicit a long-lasting, TEA-insensitive $\mathrm{K}$ conductance. Furthermore, neither caffeine nor IBMX caused an inward current (reflecting a diminution in $\mathrm{K}$ conductance) in depolarized anterior cells, such as was shown to be the case in the medial cells. Although a similar differentiation could probably be drawn on the basis of the effects of intracellular acidification in the 2 cell types, the effects of an injection of $\mathrm{H}^{+}$ were too complex in both cell types to evaluate this question adequately.

\section{The cAMP-induced cationic current in the medial cells}

The experiments on the medial cells have also revealed that the cesium-resistant cationic element of the Medial cell response is identical to the response seen in isolation in the anterior cells. The responses from the 2 cell types invert at the same potential, reveal a similar voltage dependence, and are transformed in similar ways by changes in $(\mathrm{Ca})_{0}$ and by phosphodiesterase inhibitors, intracellular acidification, and bath-applied caffeine. None of the above pharmacological effects on the inverting element of the medial cell response appear to be related to the concomitant disappearance in those cells of the cAMP-sensitive $\mathrm{K}$ conductance, as shown by the demonstration of the same effects on the inverting response in medial cells in which the noninverting element has first been eliminated by blocking all $\mathrm{K}$ conductances with an intracellular injection of cesium. 
Similarity to other nucleotide-induced slow inward currents Voltage dependence and ionic mechanisms

The cAMP-induced slow inward current described here resembles, in many respects, that activated by cGMP in the photoreceptors (Fesenko et al., 1985; Haynes et al., 1986; Zimmerman and Baylor, 1986; Matthews and Watanabe, 1987), by both cAMP and cGMP in olfactory receptor cilia (Nakamura and Gold, 1987), and by cAMP in cardiac myocytes (Egan et al., 1988). In all of these cases (see Hockberger and Swandulla, 1987), findings from whole-cell experiments performed in normal internal and external solutions reveal an outwardly rectifying current that is carricd primarily by $\mathrm{Na}$ ions passing through a rather nonselective cationic channel, as attested by a reversal potential that is in each case inferior to $E_{\mathrm{Na}}$. Furthermore, in all of these preparations, the presence of divalent cations in the extracellular milieu is inhibitory.

Insofar as estimates of elementary conductance underlying the cAMP-induced inward currents in these various preparations have been made, they appear to be remarkably similar: 20-25 pS for the current seen in photoreceptors [bathed in divalent-free intracellular and extracellular solutions (e.g., Matthews, 1987; Haynes et al., 1986)], compared to $20 \mathrm{pS}$ for the only published estimate of the elementary conductance underlying the molluscan cAMP-induced slow inward current [Green and Gillette, 1983 (made in normal seawater)]. Furthermore, the concentration of the cyclic nucleotide required for activating the current in the different preparations is in the micromolar range for all 3 of the preparations for which an estimate has been made (photoreceptors: Fesenko et al., 1985; Haynes et al., 1986; olfactory receptor cilia: Nakamura and Gold, 1987; molluscan neurons: Connor and Hockberger, 1984a; Hockberger and Yamane, 1987).

\section{Direct gating of the channel by the nucleotides}

Finally, in the 2 preparations cited above in which the effects of the nucleotides have been studied on detached membrane patches, it has been shown that the nucleotide-induced current can be elicited in solutions to which no triphosphates have been added, thus demonstrating that the conductance is gated directly by the cyclic nucleotides rather than being activated by a protein-kinase-dependent phosphorylation (see Fesenko et al., 1985; Nakamura and Gold, 1987). In molluscan neurons, a similar conclusion has been drawn from more indirect experiments. Swandulla (1987) observed that an injection of cAMP-dependent protein kinase failed to mimic the cAMP-induced slow inward current, and, as was reported here, an intracellular injection of an inhibitor of cAMP-dependent protein kinase failed to eliminate that current in cither the anterior or medial cells.

\section{Synaptic role of the cAMP-mediated slow inward current}

A cAMP-mediated current similar to that described here has been shown to be activated in other Aplysia neurons by exogeneously applied dopamine (Matsumoto et al., 1988), serotonin, and the neuropeptide $\mathrm{SCP}_{\mathrm{b}}$ (Taussig et al., 1989). Ichinose and McAdoo (1989) observed a similar current in response to FMRFamide, which they attributed to a transmitter-induced increase in cGMP. In the following paper (Kehoe, 1990), the cAMP-mediated slow inward current described here is shown to be activated in the medial cells by firing of any 1 of 3 identified presynaptic neurons. This synaptically activated current pro- longs the excitatory effects of the synaptic input for tens of seconds following the termination of presynaptic firing.

\section{References}

Adams DJ, Gage PW (1979) lonic currents in response to membrane depolarization in an Aplysia neurone. J Physiol 289:115-141.

Aldenhoff JB, Hofmeier G, Lux HD, Swandulla D (1983) Stimulation of a sodium influx by cAMP in Helix neurons. Brain Res 276:289296.

Ascher P, Nowak I. (1988) The role of divalent cations in the $N$-methyl-D-aspartate responses of mouse central neurones in cultures. J Physiol 399:247-266.

$\Lambda$ scher P, Marty A, Neild TO (1978) Life time and elementary conductance of the channels mediating the excitatory effects of acetylcholine in Aplysia neurones. J Physiol 278:177-206.

Butcher RW, Sutherland EW (1962) Adenosine 3,5'-phosphate in biological materials. I. Purification and properties of cyclic 3,5'-nucleotide phosphodiesterase and the use of this enzyme to characterize adenosine 3,5'-phosphate in human urine. J Biol Chem 237:12441250.

Calhoon RD, Gillette $\mathrm{R}$ (1983) $\mathrm{Ca}^{2+}$ activated and $\mathrm{pH}$ sensitive cyclic AMP phosphodiesterase in the nervous system of the mollusc Pleurobranchaea. Brain Res 271:371-374.

Connor JA, Hockberger P (1984a) A novel membrane sodium current induced by injection of cyclic nucleotides into gastropod neurones. $J$ Physiol 354:139-162.

Conner JA, Hockberger P (1984b) Intraccllular pH changes induccd by injection of cyclic nucleotides into gastropod neurones. J. Physiol 354:163-172.

Connor JA, Hockberger P (1985) Calcium and cAMP: second messengers in gastropod neurons. In: Model neural networks and behavior (Selverston AI, ed), pp 437-460. New York: Plenum.

DePeyer JE, Cachelin AB, Levitan IB, Reuter H (1982) Ca ${ }^{2+}$ activated $\mathrm{K}^{+}$conductance in internally perfused snail neurons is enhanced by protein phosphorylation. Proc Natl Acad Sci USA 79:4207-4211.

Egan TM, Noble D, Noble SJ, Powell T, Twist VW (1987) An isoprenaline activated sodium-dependent inward current in ventricular myocytes. Nature 328:634-637.

Egan TM, Noble D, Noble SJ, Powell T, Twist VW, Yamaoka K (1988) On the mechanism of isoprenaline- and forskolin-induced depolarization of single guinea-pig ventricular myocytes. J Physiol 400:299320.

Ewald DA, Eckert R (1983) Cyclic AMP enhances calcium-dependent potassium current in Aplysia neurons. Cell Mol Neurobiol 3:345359.

Ewald DA, Williams A, Levitan IB (1985) Modulation of single $\mathrm{Ca}^{2+}$ dependent $\mathrm{K}^{+}$channel activity by protein phosphorylation. Nature 315:503-506.

Fesenko EE, Kolesnikov SS, Lyubarsky AL (1985) Induction by cyclic GMP of cationic conductance in plasma membrane of retinal rod outer segment. Nature 313:310-313.

Gillette R, Green DJ (1987) Calcium dependence of voltage sensitivity in adenosine $3^{\prime}, 5^{\prime}$ cyclic phosphate-stimulated sodium current in Pleurobranchaea. J Physiol 393:233-245.

Green DJ, Gillette R (1983) Patch- and voltage-clamp analysis of cyclic AMP-stimulated inward current underlying neurone bursting. Nature 306:784-785.

Green DJ, Gillette R (1988) Regulation of cAMP-stimulated ion current by intracellular $\mathrm{pH}, \mathrm{Ca}^{2+}$, and calmodulin blockers. J Neurophysiol 59:248-258.

Hara N, Sawada M, Maeno T (1985) Influences of pressure injected cyclic AMP on the membrane current and characteristics of an identified neuron of Aplysia kurodai. Jpn J Physiol 35:958-1012.

Haynes LW, Kay AR, Yau K-W (1986) Single cyclic GMP-activated channel activity in excised patches of rod outer segment membrane. Nature 321:66-70.

Hockberger PE, Swandulla D (1987) Direct ion channel gating: a new function for intracellular messengers. Cell Mol Neurobiol 7:229-236.

Hockberger P, Yamane T (1987) Compartmentalization of cyclic AMP elevation in neurons of Aplysia californica. Cell Mol Neurobiol 7:1933.

Ichinose M, McAdoo DJ (1989) The cyclic GMP-induced inward current in neuron R14 of Aplysia californica: similarity to a FMRFam- 
ide-induced inward current. J Neurobiol 20:10-24.

Kehoe JS (1972a) Ionic mechanisms of a two-component cholinergic inhibition in Aplysia neurones. J Physiol 225:85-114.

Kehoe JS (1972b) Three acetylcholine receptors in Aplysia neurones. J Physiol 225:115-146.

Kehoe JS (1985a) Synaptic block of a transmitter-induced potassium conductance in Aplysia neurones. J Physiol 369:399-437.

Kehoe JS (1985b) Synaptic block of a calcium-activated potassium conductance in Aplysia neurones. J Physiol 369:439-474.

Kehoe JS (1986) Three cyclic AMP mediated excitatory currents generated in a given Aplysia neuron by the same presynaptic cell. Soc Neurosci Abst 12:14.

Kehoe JS (1990) Cyclic AMP-induced slow inward current: its synaptic manifestation in Aplysia neurons. J Neurosci 10:3208-3218.

Kononenko NI (1981) Ionic mechanisms of the transmembrane current evoked by injection of cyclic AMP into identified Helix pomatia neurons. Neurophysiology (Eng trans) 12:339-343.

Kononenko NI, Kostyuk PG, Shcherbatko AD (1983) The effect of intracellular cAMP injections on stationary membrane conductance and voltage- and time-dependent ionic currents in identified snail neurons. Brain Res 268:321-338.

Kononenko NI, Kostyuk PG, Shcherbatko AD (1986) Properties of cAMP-induced transmembrane current in mollusc neurons. Brain Res 376:239-245.

Levitan IB (1985) Phosphorylation of ion channels. J Memb Biol 87: 177-190.

Levitan IB (1988) Modulation of ion channels in neurons and other cells. Ann Rev Neurosci 11:119-136.

Liberman EA, Minna SV, Golubtsov KV (1975) The study of the metabolic synapse. I. Effect of intracellular microinjection of $3^{\prime}, 5^{\prime}$ AMP. Biophys (Moscow) 20:451-457.

Matsumoto M, Sasaki K, Sato M, Shozushima M, Takashima K (1988) Dopamine-induced depolarizing responses associated with negative slope conductance in LB-cluster neurones of Aplysia. J Physiol 407: 199-213.
Matthews G (1987) Single-channel recordings demonstrate that cGMP opens the light-sensitive ion channel of the rod photoreceptor. Proc Natl Acad Sci USA 84:299-302.

Matthews G, Watanabe S-I (1987) Properties of ion channels closed by light and opened by guanosine $3^{\prime}, 5^{\prime}$-cyclic monophosphate in toad retinal rods. J Physiol 389:691-715.

Meech RW, Thomas RC (1987) Voltage-dependent intracellular pH in Helix aspersa neurones. J Physiol 390:433-452.

Nakamura T, Gold GH (1987) A cyclic nucleotide-gated conductance in olfactory receptor cilia. Nature 325:442-444.

Sharp AP, Thomas RC (1981) The effects of chloride substitution on intracellular pH in crab muscle. J Physiol 312:71-80.

Shuster MJ, Camardo JS, Siegelbaum SA, Kandel ER (1985) Cyclic AMP-dependent protein kinase closes the serotonin-sensitive $\mathrm{K}^{+}$ channels of Aplysia sensory neurons in cell-free membrane patches. Nature 313:392-395.

Swandulla D (1987) Cationic membrane conductances induced by intracellularly elevated cAMP and $\mathrm{Ca}^{2+}:$ measurements with ion-selective microelectrodes. Can J Physiol Pharmacol 65:898-903.

Swandulla D, Lux HD (1984) Changes in ionic conductances induced by cAMP in Helix neurons. Brain Res 305:115-122.

Taussig R, Sweet-Cordero A, Scheller RH (1989) Modulation of ionic currents in Aplysia motor neuron B15 by serotonin, neuropeptides, and second messengers. J Neurosci 9:3218-3229.

Thomas RC, Meech RW (1982) Hydrogen ion currents and intracellular $\mathrm{pH}$ in depolarized, voltage-clamped snail neurones. Nature 299 : 826-828.

Walsh JP, Byrne JH (1989) Modulation of a steady state $\mathrm{Ca}^{2+}$ activated $\mathrm{K}^{+}$current in tail sensory neurons of Aplysia: role of serotonin and cAMP. J Neurophysiol 61:32-44.

7immerman AI, Baylor DA (1986) Cyclic GMP-sensitive conductance of retinal rods consists of aqueous pores. Nature 321:70-72. 